\title{
Evaluation of Cocoa Agribusiness in South Manokwari Regency, West Papua, Indonesia
}

\author{
Junita Br. Nambela $\left.{ }^{1 *}\right)$ and Aser Rouw ${ }^{1)}$ \\ ${ }^{1)}$ West Papua Assessment Institute for Agricultural Technology \\ Indonesian Agency for Agricultural Research and Development \\ Jn. Trikora Anday Kompleks Kawasan Terpadu Kementerian Pertanian Manokwari, \\ Papua Barat 98315, Indonesia \\ Corresponding author: junitanambela@gmail.com \\ Received: 24 May 2020 / Accepted: 11 September 2020
}

\begin{abstract}
South Manokwari has triumphed with cocoa since 1980 but that glory has faded in recent years. Recently, this regency is faced with various problems for the development of cocoa agribusiness. The purpose of the study was to evaluate the current cocoa-based business in South Manokwari. This research was conducted in three districts in South Manokwari namely Oransbari, Ransiki, and Momi Waren. The study was conducted using the purposive random sampling technique on 119 respondents. The distribution of respondents in the three districts was: Oransbari 44 respondents; Ransiki 42 respondents; and Momi Waren 33 respondents. Based on the study results, it was known that the average plantation ownership by the farmers was 1.09 ha. Ninety nine percent of farmers were still in productive age (15-65 years). The level of education was still low with $67.13 \%$ of farmers had no formal education or did not finish elementary school. Cultivation practices that must be improved included pruning $(74.71 \%)$, fertilization $(95.89 \%)$, pest and disease control $(55.16 \%)$, and waste utilization $(82.07 \%)$. The cocoa beans' average production was in the range of $71.67-173.33 \mathrm{~kg}$ dry beans or $21.67-1000 \mathrm{~kg}$ fresh beans per ha harvested from 1,574 ha of farmers' cocoa land in South Manokwari. Meanwhile, the average prices for cocoa beans were USD $0.24-$ USD $0.36 / \mathrm{kg}$ for the fresh beans and USD $1.20-$ USD $2.23 / \mathrm{kg}$ for the dried beans.
\end{abstract}

Keywords: Evaluation, cocoa, South Manokwari, agribusiness

\section{INTRODUCTION}

Superior commodities are important pillars that must be managed optimally to increase regional economic competitiveness. The main estate crop commodities of West Papua province based on the potential land area and its products consisted of four commodities, namely palm oil, cocoa, coconut, and nutmeg. Cocoa ranked second in terms of production and third in terms of land area (Sari, 2014). The three districts in West Papua that had the highest cocoa production in 2019 were Manokwari, South Manokwari, and Tambrauw (BPS Papua Barat, 2020). Meanwhile, the largest area of cocoa plantations was located in South Manokwari, which consisted of 5,509 ha or about $50 \%$ of the total area of cocoa plantations in West Papua (Rouw, 2019).

South Manokwari had already been succeeding in cocoa production through the cocoa development program by the IJJDF (Irian Jaya Joint Development Foundation) and the government. The IJJDF is one of 
the representatives of the international agency UNDP (United Nations Development Program). It was recommended by the Fundwi Survey Mission in 1967. The foundation was legally established in December 1970. UNDP and the Indonesian government each provided $\$ 4$ million for the Foundation and more than half of the funds had been made available by the end of 1972. The Foundation investmented in form of management assistance and company technical aspects (IJJDF, 2020).

In the beginning, PT Coklat Ransiki (PT Cokran) was a private cocoa plantation that involved the local Arfak community as workers (Matanubun et al., 1995). This company was noted to have developed more than 20,000 ha of cocoa plantation. In addition, cocoa bean production was produced through smallholder plantations that were developed by the communities themselves. Smallholder plantations were concentrated in Manokwari Regency such as around Oransbari, Ransiki, Warmare, and Prafi (BPPD Papua Barat, 2007). During the last period, two types of cocoa ownership were developed namely the private cocoa plantations under the management of PT Cokran and the cocoa plantations owned by local communities. The success of South Manokwari cocoa at that time was supported by the level of agro-ecosystem suitability and good management of the entire cocoa business chain. Whereas, South Manokwari is now facing various problems in the development of cocoa agribusiness. In general, cocoa commodity problems in South Manokwari include declining production due to the age of cocoa trees (more than 30 years), minimal management, lack of good harvest and post harvest practices, and absence of farmer's local institution. This situation is worsened by the cocoa pod borer (CPB) and Phytophthora palmivora that attack all cocoa-producing centers in Indonesia including South Manokwari. This was also published in ICCO's 2017 annual report which mentioned that in the 2014/ 2015 season, Asia and Oceania experienced a decline in cocoa production of nearly $11 \%$ to 400,000 tons, with Indonesia accounting for most of the decline in production. This decrease in production was caused by pests, diseases, and aging cocoa trees (ICCO, 2017).

Currently, South Manokwari cocoa bean production has not been able to meet the increasing market demand. Because of that, South Manokwari regional government is trying to increase cocoa production to increase to the community income and regional revenue. To plan the improvement strategies and followup plans, data, and information was needed regarding the current state of cocoa plantations and production. This study aimed to investigate the current cocoa-based business in South Manokwari that included several aspects: average area of plantation ownership, the average age of farmers, farmers' education level, cultivation practices, harvest, and post-harvest processes, production, farmers income, and waste utilization.

\section{MATERIALS AND METHODS}

This research was conducted in South Manokwari Regency which covered three districts namely Ransiki, Oransbari, and Momi Waren. The study was conducted in 2018. The location was determined with the consideration that the three selected districts were the districts with the largest area of cocoa plantations among the six districts in South Manokwari Regency. Sampling in this study used a purposive random sampling technique on 119 respondents. This study used a survey method using a questionnaire that contained a list of questions and direct interviews. The sampling technique used accidental sampling, where respondents who incidentally meet with the researcher, if it 
is seen by the person who happens to be found suitable as a source of data. This approach was taken considering that the area of South Manokwari was 278.900 ha while the number of cocoa farmers was 180 . This means that each cocoa farmer was distributed in every 1.600 ha. The observed variables included: farming area, farmer's age, farmer's education, seed source, planting spacing, cropping pattern, pruning, fertilizing, pest and disease control, types of cocoa pests, types of cocoa diseases, weed control, harvesting, post-harvest, seed processing, waste utilization, crop yields, selling prices, and potential income of farmers. The data obtained were then tabulated and analyzed using descriptive analysis. The distribution of research respondents in 3 districts in South Manokwari came from 18 villages as shown in Table 1.

\section{RESULTS AND DISCUSSION}

\section{Cocoa Farm Area}

The average cocoa plantation ownership per farmer in Ransiki district was larger, while smaller cocoa land in Momi Waren (Table 2). The farm ownership area for cocoa in South Manokwari Regency varied between 0.25 ha to 2 ha. Ideally, a minimum area for cocoa cultivation is 2 ha per farmer. With a small farmland, it is difficult for farmers to implement technological innovations appropriately because high operational costs or low efficiency. Besides, farmers do not have enough capital to develop cocoa cultivation adequately. Farmers generally do not master the latest technological innovations because of their low level of knowledge or because of a lack of information about the latest

Table 1. The distribution of respondents in three districts in South Manokwari Regency

\begin{tabular}{|c|c|c|c|}
\hline District & Location/Village & Farm area (ha) & Respondent number \\
\hline \multirow[t]{7}{*}{ Ransiki } & 1 Cooperative Ebier Suth & 843 & - \\
\hline & 2 Sabri & 80 & 8 \\
\hline & 3 Nuhuwei & 35 & 6 \\
\hline & 4 Tobouw & 100 & 15 \\
\hline & 5 Abreso & 67 & 9 \\
\hline & 6 Susmorof & 15 & 4 \\
\hline & Total & 1140 & 42 \\
\hline \multirow[t]{6}{*}{ Momi Waren } & 1 Dembek & 50 & 7 \\
\hline & 2 Demini & 30 & 6 \\
\hline & 3 Siwi & 50 & 7 \\
\hline & 4 Waren & 25 & 7 \\
\hline & 5 Gaya Baru & 15 & 6 \\
\hline & Total & 170 & 33 \\
\hline \multirow[t]{10}{*}{ Oransbari } & 1 Warbiadi & 39 & 7 \\
\hline & 2 Watariri & 40 & 4 \\
\hline & 3 Wandoki & 25 & 4 \\
\hline & 4 Masabui & 40 & 5 \\
\hline & 5 Waroser & 15 & 5 \\
\hline & 6 Oransbari & 35 & 0 \\
\hline & 7 Muari & 35 & 10 \\
\hline & 8 Sidomulyo & 35 & 9 \\
\hline & Total & 264 & 44 \\
\hline & Grand total & 1,574 & 119 \\
\hline
\end{tabular}


technological innovations (Rubiyo \& Siswanto, 2012).

Table 2. Cocoa farm ownership average area in three districts

\begin{tabular}{lc}
\hline District & Cocoa farm ownership (ha) \\
\hline Ransiki & 1.23 \\
Momi Waren & 0.95 \\
Oransbari & 1.09 \\
Average & 1.09 \\
\hline Note: Smallest farm ownership area is 0.25 ha and the
\end{tabular}

\section{Age}

In general, the age of a farmer greatly influences his agribusiness capability, because age is one of the factors that affect one's physical ability to work and ways of thinking, especially in terms of decision making (Yasa \& Hadayani, 2017). The age of cocoa farmers in the South Manokwari Regency is $98.99 \%$ were still in productive age, which is in the age range of 15-65 years (Figure 1). The age distribution of farmers in Ransiki and Oransbari Districts was $100 \%$ in productive age, while the age distribution of farmers in the Momi Waren District is $96.97 \%$ of productive age and the remaining $3.03 \%$ are in unproductive age $(<15$ years and $>65$ years $)$.

\section{Education}

Yulianti (2015) stated that someone's education, in general, will affect the way of thinking. With education, a person will have extensive knowledge, easy to develop ideas, easy to adopt technology, and increasingly dynamic attitudes towards new things, especially in the face of more modern changes. The level of education of cocoa farmers in the research location is still relatively low. Larger proportion (75\%) of cocoa farmer in Momi Waren district have education less than junior high school (Figure 2). The average percentage of farmers' education who did not attend school/dropped out of school was $37.73 \%$, finished elementary school was $29.40 \%$, finished junior high was $14.39 \%$, finished senior high was $15.15 \%$ and finished higher education was $3.32 \%$. Education greatly influences the ability of farmers to adopt technological innovations for cocoa cultivation. Therefore, efforts and appropriate ways to get around this situation where needed. The continuous farmer assistance method can be chosen as the solution.

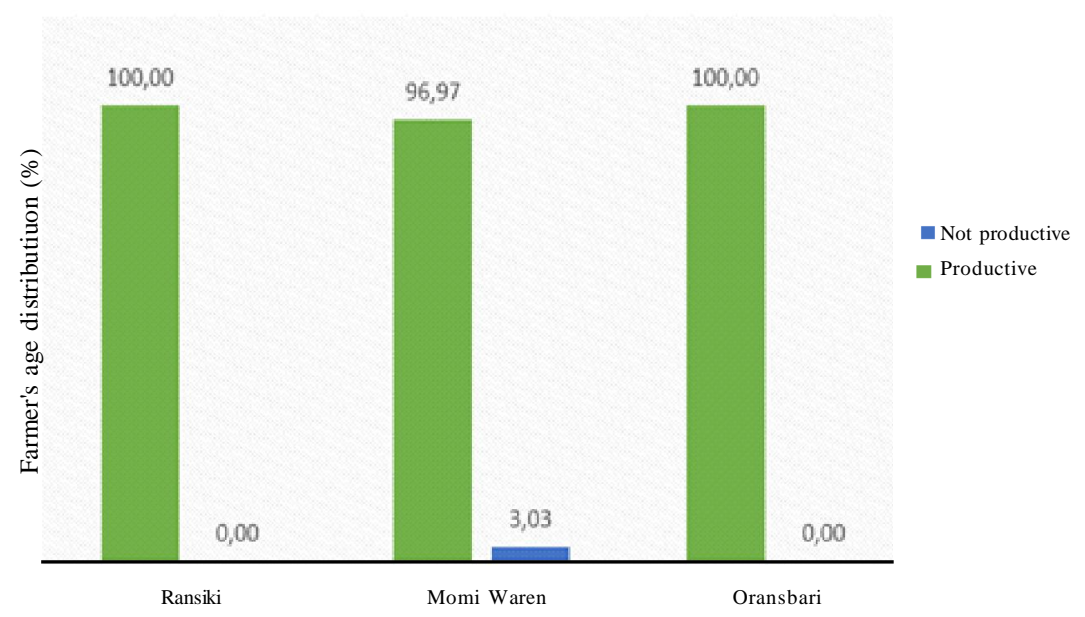

Figure 1. Farmer's age distribution in three cocoa producing districts in South Manokwari

Notes: Productive; 15 years to 65 years, and not productive; $<15$ years and $>65$ years 


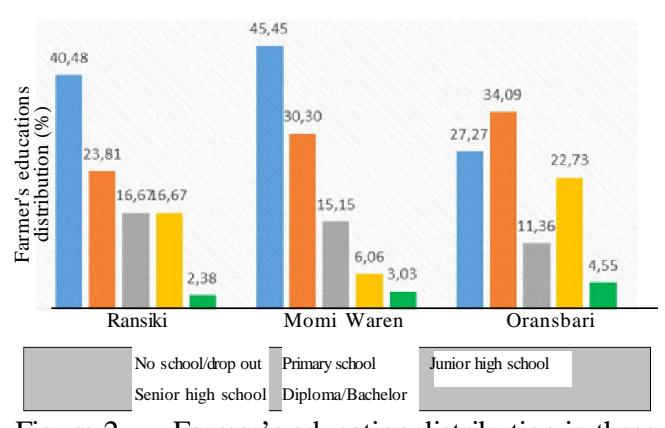

Figure 2. Farmer's education distribution in three cocoa producing districts in South Manokwari

\section{Seed Source}

To increase the production and quality of cocoa beans, especially in smallholder plantations, superior varieties that have high production potential, high-quality beans, and more resistant to pests and diseases are needed (Rubiyo, 2013). The source of seeds planted by farmers mostly $(80.55 \%)$ came from government support, while the rest (13.88\%) bought the seeds from the market (Figure 3). In other words, the quality of most cocoa seeds was still guaranteed because seeds from government aid have passed the quality control process before being distributed to the community.

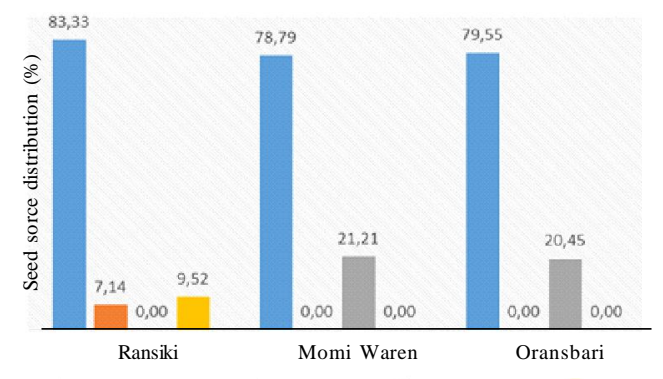

mGovernment assistance $\equiv$ Inherited parents $\approx$ Buy on the market $=$ Others

Figure 3. Seed source distribution in three cocoa producing districts in South Manokwari

\section{Plant Spacing}

Based on the research results of Hayata \& Febrina (2019) cocoa seedling planted within a distance of $5.5 \mathrm{~m} \times 6.0 \mathrm{~m}$ produced a better yield of fresh bean and dry bean compared to those planted within a distance of $4.2 \mathrm{~m} \times 4.5 \mathrm{~m}$. Humidity at narrower planting distances tended to be higher than wider planting distances. The percentage of plant spacing practice can be seen in the Figure 4. Farmers in South Manokwari predominantly used the common spacing of $4 \mathrm{~m} \times 3 \mathrm{~m}$ or $4 \mathrm{~m} \times 2 \mathrm{~m}$, but some seedlings were planted irregularly. As many as $95.82 \%$ of farmers used common spacing while the remaining $4.18 \%$ of farmers planted irregularly (with no spacing) where all farmers in Oransbari planted cocoa in regular distance.

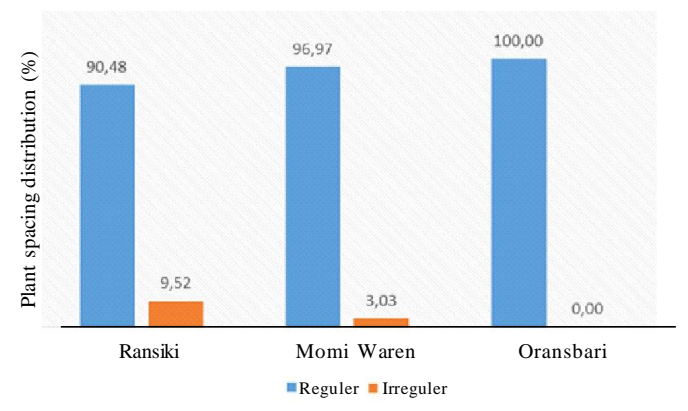

Figure 4. Plant spacing distribution in three cocoa producing districts in South Manokwari

\section{Cropping Pattern}

Cocoa farmers in South Manokwari grew cocoa both by monoculture and intercropping patterns. Ransiki district applied the monoculture cropping pattern more than Oransbari. The choice of cropping pattern is related to the needs of farmers. Some farmers still applied intercropping pattern because the family food security was the main goal. Figure 5 showed that most cocoa farmer in Oransbari applied intercropping pattern. Types of plants intercropped with cocoa in South Manokwari included: banana, areca nut, and coconut. 


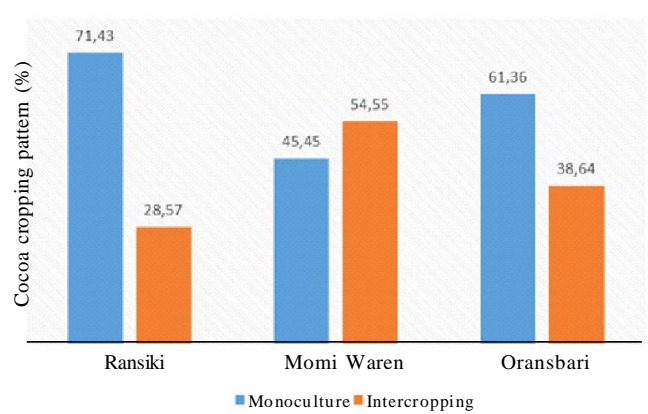

Figure 5. Cocoa cropping patterns in three cocoa producing districts in South Manokwari

\section{Pruning}

According to the results published by Angela \& Efendi (2015), pruning affected the number of side shoots, budding flower cushions, cherelle, and fruit resistance against pests and plant diseases. Pruning rotation also affected the stability of annual cocoa beans production. Pruning also reduced humidity per plant because the plants get enough sunlight. In Figure 6 it can be seen that the percentage of routine pruning in the districts of Momi Waren and Oransbari on average is $27.27 \%$ and followed by the Ransiki district at $19.05 \%$. The average percentage of plants not pruned is quite high at $74.71 \%$. Labor limitations and lack of information related to pruning and their effects on the quantity and quality of cocoa produced were the causes.

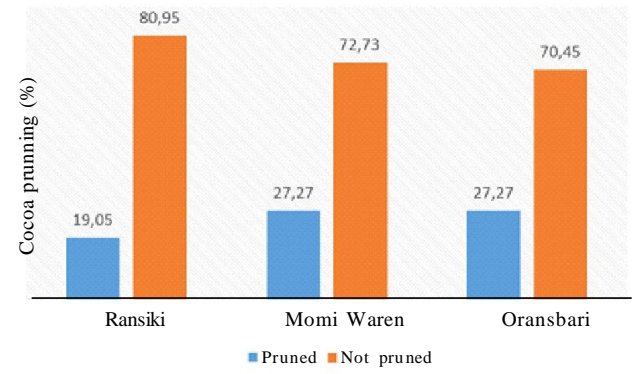

Figure 6. Cocoa pruning in three cocoa producing districts in South Manokwari

\section{Fertilization}

To achieve optimal cocoa productivity, balanced nutrients are needed for its growth and production. Therefore, balanced fertilization is the key to success in farming. The dosage and method of inorganic fertilizer had a significant effect on the growth of immature cocoa, especially on leaf area parameters, leaf chlorophyll index, flush amount, and flush length. Application of $90 \mathrm{~g}$ of NPKMg (20: 10:10:2) fertilizer per plant was able to give the best growth of immature cocoa plant Sulawesi 1 clone (Lumbantobing, 2019). Correspondingly, NPK fertilizer application (16-16-16) significantly affected plant height, stem diameter, total leaf area, and root canopy ratio (Marpaung, 2013). As for crop yields, nitrogen fertilization improves the physical and chemical quality of cocoa beans in Punung, Pacitan. The optimum dosage of $\mathrm{N}$ as urea fertilizer to improve the physical quality of cocoa beans is $870 \mathrm{~g} /$ tree/year, while the chemical quality is at a dose of $820 \mathrm{~g} /$ tree/year (Utami et al., 2018).

The distribution of the fertilization practice in South Manokwari can be seen in Figure 7.

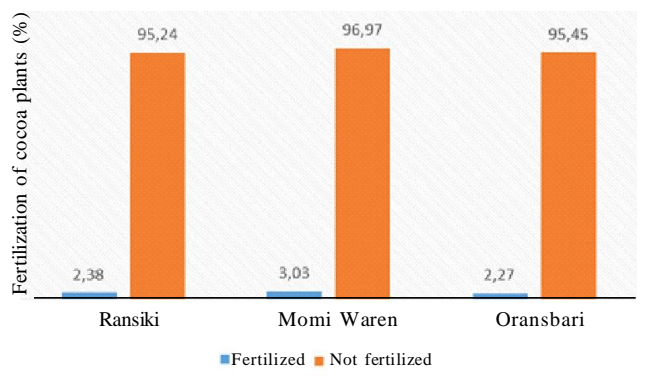

Figure 7. Fertilization of cocoa plants in three cocoa producing districts in South Manokwari

Farmers in South Manokwari in 2005 until 2018 mostly did not fertilize their cocoa plants. The average percentage of farmers who fertilized was only $2.56 \%$, while the rest did not fertilize their cocoa trees. This 
was caused by of the scarcity of fertilizers on the market and the insufficient budget to buy fertilizers based on their income from cocoa farming. Besides, cocoa farming was not the main source of income for the farmer because the trees did not produce well anymore.

\section{Pest and Disease Control}

Extensive development of cocoa is always facing obstacles, among others, by the presence of pests and diseases. Economic loss due to pests and diseases are very unpredictable and expensive. The average percentage of damaged cocoa beans by Conopomorpha cramerella or cocoa pod borer varied from $18.45 \%$ to $50.20 \%$ (Azim et al., 2016). Besides that, the average damage intensity of cocoa pod rod disease in Taniwel district was $21.8 \%$. The amount of loss caused by pests and diseases requires farmers to control it quickly and accurately (Matitaputty et al., 2014). In South Manokwari, most cocoa farmers still controlled cocoa pests and diseases both chemically (Figure 8). Chemical control was usually carried out using insecticides and fungicides. The highest pest and disease control practices were found in Momi Waren district. Meanwhile, higher precentage of farmers in Oransbari did not controlled their cocoa farms from pests and diseases.

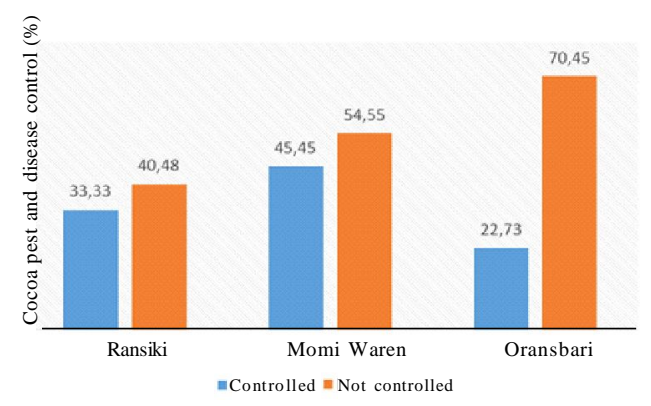

Figure 8. Cocoa pest and disease control in three cocoa producing districts in South Manokwari

\section{Types of Cocoa Pests}

Figure 9 shows the types of pests and the percentage of attacks cocoa farms in South Manokwari. Cocoa farmers identified five types of pests that most often attacked their cocoa plants namely, cocoa pod borer (Conopomorpha cramerella), cocoa pod sucker (Helopeltis,spp. Amblypelta spp, Distantiella spp.), cocoa stem borer (Zeuzera coffeae), rat and squirrel. From the study results it is known that the cocoa pod borer (Conopomorpha cramerella) is the main pest with an average percentage attack rate that is much higher than other pests, which is $78.03 \%$.

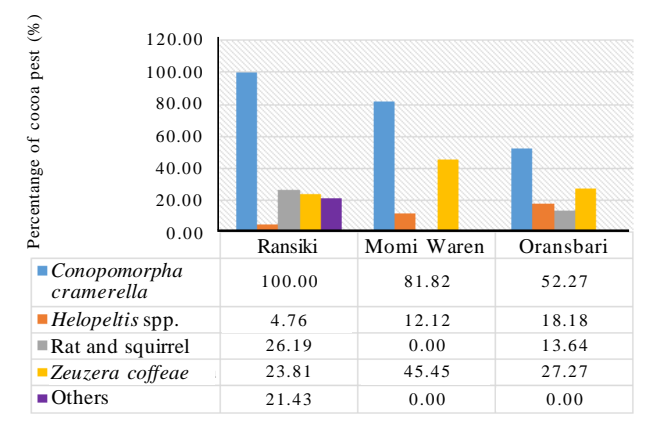

Figure 9. Cocoa pests in three cocoa producing districts in South Manokwari

\section{Types of Cocoa Disease}

The most common diseases affecting cocoa in South Manokwari can be seen in Figure 10. Three diseases that often attack cocoa were pod rot disease (Phytophthora palmivora); stem cancer; and vascular streak dieback (VSD). This study results show that pod rot (Phytophthora palmivora) was a major disease with a percentage of attacks of $61.51 \%$ for South Manokwari. 


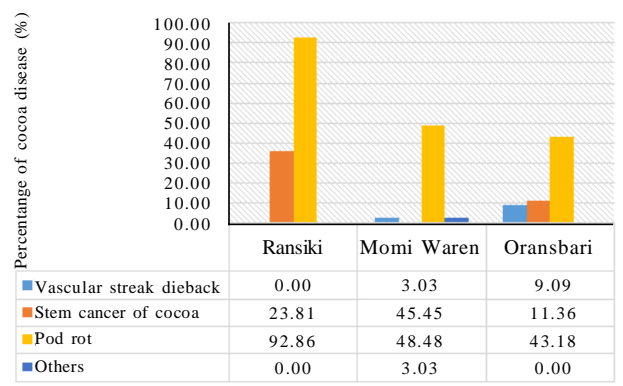

Figure 10. Cocoa diseases in three cocoa producing districts in South Manokwari

\section{Weed Control}

Figure 11 illustrates weed control measures under cocoa trees by farmers in South Manokwari. Most farmers in the Ransiki District still carried out weed control, especially mechanical control. Whereas in the other two districts Momi Waren and Oransbari, mostly farmers did not do weed control. In the Ransiki district, chemical control was rarely carried out due to limited budget and limited facilities such as spray equipment to implement the measure. Farmers tended to choose mechanical control because it is considered cheaper.

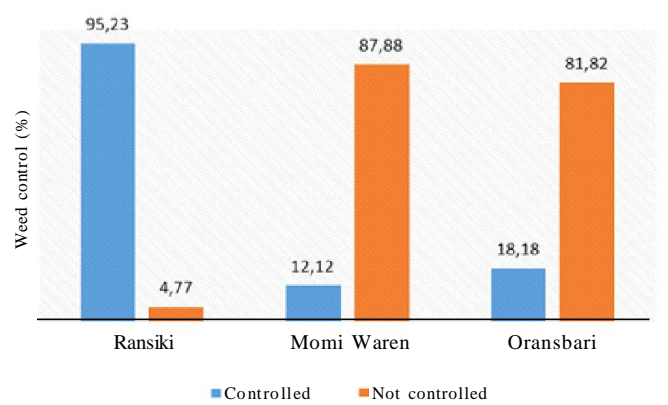

Figure 11. Weed control of cocoa plants in three cocoa producing districts in South Manokwari

\section{Harvesting}

Figure 12 illustrates the harvesting practices carried out by South Manokwari cocoa farmers. Harvesting is the activity of picking pods from a tree and breaking it down to utilize the fresh beans inside. To achieve the yield target and to obtain high productivity, proper harvest management is needed. Harvest management consists of harvest organization and harvesting system. Mistakes in harvest management will affect the implementation of on-farm harvesting activities which in turn will have an impact on the level of yield produced and the quality of the fruit harvested (Anna, 2011). In general farmers in South Manokwari still harvested their cocoa. What needs to be underlined was the harvesting practice, which was still not quite right, where many farmers did not harvest cocoa based on the harvesting standards. Many farmers harvested the cocoa fruit when it was not yet fully ripe so that the results obtained are not optimal both in terms of weight and quality of the beans. Ransiki District had the highest number of farmers who still harvest their cocoa (100\%), followed by Momi Waren (96.97\%), and Oransbari (34.09\%). In the Oransbari district, it is known that the lowest percentage of cocoa harvested is due to uncontrolled pests and diseases that attack their cocoa. The very high level of pest attack caused a drastic decrease in production and quality so that many farmers decided not to harvest their cocoa anymore. The damage and spread of pests and diseases of cocoa are getting worse due to the lack of fertilization and cocoa farmland sanitation including weed control.

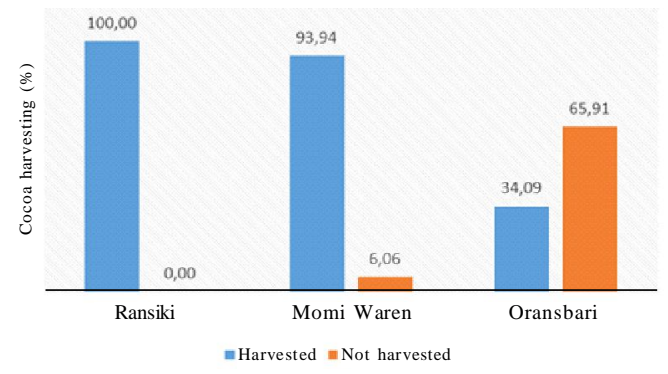

Figure 12. Cocoa harvesting in three cocoa producing districts in South Manokwari 


\section{Post-harvest}

The post-harvest activities include pod breaking, fermentation, and cocoa drying. After the fruits were harvested, they immediately broke the pods, and took the fresh beans. Some farmers delayed the pod breaking and stored it for sometimes instead, because of limited labor. The percentage of the aforementioned practice is presented in Figure 13.

In three districts surveyed, Oransbari showed the largest number in performing direct pods peeling or the smallest in waiting for the pods to ripe. Up to $74 \%$ of respondents admitted that they immediately peeled the pods after harvest, $25 \%$ left the pods to ripe and the remaining $1 \%$ of respondents did not respond. According to Amran, et al. (2018), ripening cocoa pods aims to support the formation of cocoa flavor and aroma as well as to accelerate fermentation process since ripening would cause cocoa pulps to detach more easily from their beans. Ripening time ranges from 6-9 days. During ripening process, there would also be a decrease in cocoa beans' moisture content so that after pods peeling the drying time might be shorter.

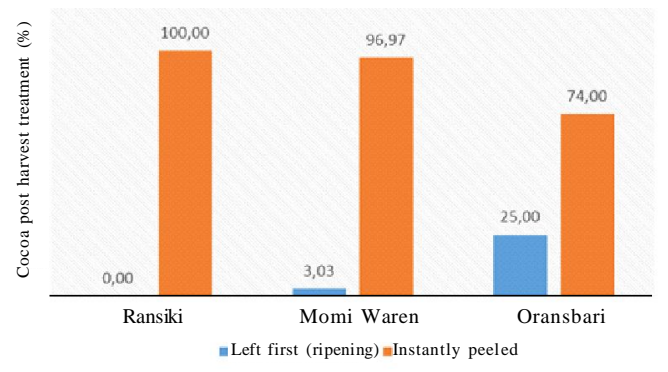

Figure 13. Cocoa post-harvest treatment in three cocoa producing districts in South Manokwari

\section{Beans Processing}

Figure 14 below shows the processing of cocoa beans by farmers in South Manokwari. Cocoa beans processing performed by the farmers was simple fermentation. Farmers in South Manokwari are generally aware of the importance of cocoa beans fermentation. Therefore, most farmers have carried out fermentation for their cocoa beans. An average of $82.54 \%$ of respondent farmers has fermented their cocoa beans. Regardless of whether the process was carried out properly or not, at least most farmers already have a better understanding of the importance of fermentation to achieve good quality of cocoa beans. The method most commonly used by farmers in South Manokwari is filling up plastic sacks with peeled wet cocoa beans then leaving them to drain for 2-7 days. After considered sufficiently fermented, cocoa beans were sun-dried. The drying process was carried out traditionally with sun-drying on a sheet of tarpaulin. Drying time is not specified but based on self-determined standards.

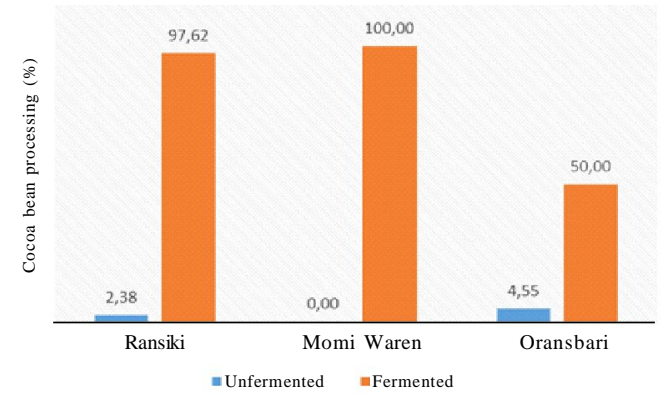

Figure 14. Cocoa bean processing in three cocoa producing districts in South Manokwari

Cocoa beans fermentation is very important since it induces drastic biochemical changes in types and concentrations of flavor precursors in cocoa beans (Kadow et al., 2013; Krahmer et al., 2015). Based on this study data, yields obtained by fermentation process in higher percentage is in Momi Waren (100\%). Oransbari district has the lowest beans fermentation rate due to a very high level of pest infestation that has caused decreases in cocoa production and quality so that many farmers did not harvest their cocoa pods. In addition, for farmers who still harvested their cocoa pods, they tended 
to ignore the processing and quality of their beans yields.

\section{Waste Utilization}

Most farmers still discarded their unutilized wastes. About $97.22 \%$ of farmers considered cocoa pods and umbilical cords (funiculus) to have no economic value at all. The pods mostly were just being stacked and left to dry. About $2.77 \%$ of farmers pile it up or buried it in soil. The waste utilization practices is shown in Figure 15.

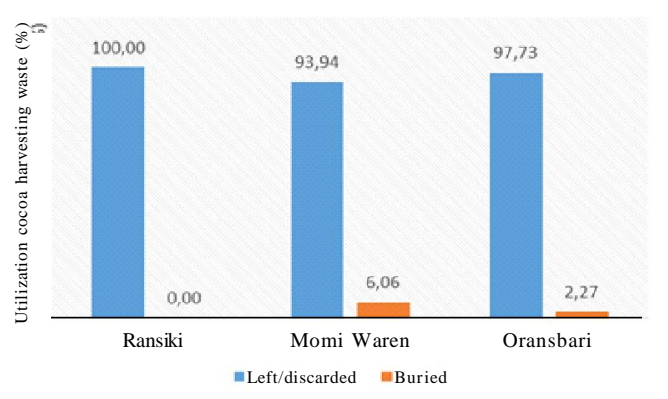

Figure 15. Utilization of cocoa harvesting waste in three cocoa producing districts in South Manokwari

The best treatment for cocoa pod husks and harvest waste is to bury them in the soil. This has a good impact on the cocoa plant because the pod husks can be a source of organic matter. This is by the results of research by Saragih \& Ardian (2017) which states that giving cocoa pod husk compost has a significant effect on the increase in plant height, leaf area, and stem circumference in immature cocoa plants. Also, burying the pod husks and harvest waste can prevent and minimize the spread of cocoa pests and diseases such as the cocoa pod borer (Conopomorpha cramerella), cocoa pod sucker (Helopeltis sp, and other) and pod rot disease (Phytophthora palmivora).

\section{Annual Cocoa Beans Amount Sold}

The number of cocoa beans sold per year which are harvested from 1.574 ha of cocoa land and the cooperative consists of two types, namely fresh beans and dry beans. Details of the number of fresh and dry one can be seen in the Table 3 . It can be observed that there were still many farmers who sell their cocoa in form of fresh beans. This usually caused by pressure on household financial needs. Also, in South Manokwari, there was still a barter system for farmers' crop products. Cocoa beans usually were exchanged for groceries. Farmers in the Ransiki District had the highest number of fresh cocoa beans trade, which is between 200-250 kg per season. Based on Table 2 above it was known that the highest dried beans production was in Ransiki District $1,500 \mathrm{~kg}$, followed by Oransbari and Momi Waren with 1,000 and $500 \mathrm{~kg}$ respectively. The average production of dried beans per season is $1,000 \mathrm{~kg}$.

Table 3. Cocoa beans amount sold per year from 1,574 ha

\begin{tabular}{lcccr}
\hline \multirow{2}{*}{ District } & \multicolumn{2}{c}{ Fresh bean $(\mathrm{kg})$} & \multicolumn{2}{c}{ Dry bean $(\mathrm{kg})$} \\
\cline { 2 - 5 } & Lowest & Highest & Lowest & Highest \\
\hline Ransiki & 200 & 250 & 25 & 1,500 \\
Momi waren & 15 & 120 & 10 & 500 \\
Oransbari & 0 & 150 & 30 & 1,000 \\
Total & 215 & 520 & 65 & 3,000 \\
Average & 72 & 173 & 22 & 1,000 \\
\hline
\end{tabular}


Cocoa productions in the form of dried beans varied greatly in both quantity and quality between each farmer. The fermentation and drying process did require more time and energy for farmers, but they deemed it comparable to the higher price of dried cocoa beans which was quite good. Some farmers used dried beans as savings. They would store the dried beans for some time and were only sold it when they needed money.

\section{Cocoa Price}

Data on the cocoa beans' price in South Manokwari can be seen in Table 4. The selling price shown below is the price of cocoa that was available when data was collected. The cocoa price varies between $0.22-0.36$ USD per $\mathrm{kg}$, while the price for dry cocoa varies between $0.58-2.52$ USD per $\mathrm{kg}$.

The price of fresh cocoa beans was incredibly low compared to the price of dried cocoa beans. This was because the middlemen (cocoa collectors) still needed to do the fermentation and drying process by themselves before they could sell it again to the cocoa industry.
Labor costs incurred by the collectors caused a relatively large price difference. Farmers had a low bargaining position due to the pressure on their financial needs.

Meanwhile, the price of dried cocoa fluctuated depending on market demand and the quality of the beans produced. Between the three cocoa center districts in South Manokwari, there were still price differences. This showed that middlemen of cocoa beans still played a large role in determining the purchase price and farmers could only accept it.

\section{Potential Income}

The potential income of cocoa farmers per year in South Manokwari can be seen in the Table 5. The maximum income per district per year from cocoa agribusiness by selling wet cocoa beans is higher in district of Ransiki (USD 81.03) than Momi Waren, and Oransbari. Therefore, if maximum income in those districts district per year is from cocoa agribusiness by selling dried cocoa beans the highest in the district of Ransiki.

Table 4. Selling price per kilogram of coca bean in four districs

\begin{tabular}{lcccc}
\hline \multirow{2}{*}{ District } & \multicolumn{2}{c}{ Cocoa bean price (USD) } & \multicolumn{2}{c}{ Dry cocoa bean price (USD) } \\
\cline { 2 - 5 } & Lowest & Highest & Lowest & Highest \\
\hline Ransiki & 0.29 & 0.36 & 1.73 & 2.52 \\
Momi Waren & 0.22 & 0.36 & 0.30 & 2.16 \\
Oransbari & 0.22 & 0.36 & 1.20 & 2.02 \\
Average & 0.24 & 0.36 & 2.23 \\
\hline
\end{tabular}

Table 5. Potential income per year based on selling fresh and dry cocoa bean

\begin{tabular}{lcrrr}
\hline \multirow{2}{*}{ Income } & \multirow{2}{*}{ Selling price position } & \multicolumn{2}{c}{ Potential income per year (USD) } \\
\cline { 3 - 5 } Fresh cocoa beans & & Ransiki & Momi Waren & Oransbari \\
& Lowest & 64.83 & 4.32 & 2.88 \\
Dry cocoa bean & Highest & 81.03 & 34.57 & 43.22 \\
& Lowest & 53.12 & 17.29 & 38.90 \\
\hline
\end{tabular}




\section{CONCLUSIONS}

Based on the evaluation results of current cocoa based business evaluation in South Manokwari Regency, West Papua, it is founded that the seed source mostly came from government aid; farmers used plant spacing; farmers planted using monoculture pattern; cocoa trees which were not pruned the cocoa trees were not fertilized; pests and diseases were uncontrolled; the dominant type of pest was Conopomorpha cramerella; the most common disease type was Phytophthora palmivora; weed control practice was not carried out; most cocoa trees were still harvested; after harvest, the cocoa pods were immediately peeled; and then fermented; the waste was mostly just being discarded. The range of dried beans production was between $71.67 \mathrm{~kg}-173.33 \mathrm{~kg}$ per year dried per year from 1,574 ha cocoa farmland in South Manokwari. The prices for cocoa beans from January to April 2018 were in range of USD 0.24 - USD $0.36 / \mathrm{kg}$ for the fresh beans and USD 1.20-USD $2.23 / \mathrm{kg}$ for the dried beans.

\section{ACKNOWLEDGEMENTS}

This work was supported by South Manokwari Agriculture and Food Security Service and Board of Ebier Suth Cokran Cooperative. We wish to thank also to Mimin Yulita Kusumaningrum and Nicolays Jambang for their contribution and advice for this research paper.

\section{REFERENCES}

Ambarita, P. \& N. Kartika (2015). Pengaruh luas lahan, penggunaan pestisida, tenaga kerja, pupuk terhadap produksi kopi di Kecamatan Pekutatan Kabupaten Jembrana. E-Jurnal Ekonomi Pembangunan Universitas Udayana, 4, 746-872.
Amran ; I. Rahim; Darmawan (2018). Penanganan pascapanen kakao (Theobroma cacao $L$.) pada tingkat petani di Desa Kalukku, Kecamatan Kalukku, Kabupaten Mamuju. Prosiding Seminar Nasional Sinergitas Multidisiplin Ilmu Pengetahuan dan Teknologi (SMIPT), 1, 185-190.

Angela \& D. Efendi (2015). Pengelolaan pemangkasan tanaman kakao (Theobroma cacao L.) di Cilacap, Jawa Tengah. Buletin Agrohorti, 3, 285-293.

Anna, O.N. (2011). Pengelolaan Panen dan Pascapanen Tanaman Kakao (Theobroma cacao L.) di Kebun PT Rumpun Sari Antan 1, Cilacap, Jawa Tengah. Skripsi. Institut Pertanian Bogor, Bogor.

Azim, S.F.; D.S. Kandowangko \& N.N. Wanta (2016). Kerusakan biji kakao oleh hama penggerek buah (Conopomorpha cramerella Snellen) pada pertanaman kakao di Desa Muntoi dan Solimandungan. Journal Cocos Universitas Sam Ratulangi, 7, 1-8.

BPS (2020). Provinsi Papua Barat Dalam Angka. Badan Pusat Statistik Provinsi Papua Barat. CV. Nario Sari. Manokwari.

BPPD Papua Barat (2007). Laporan Akhir Rencana Pengembangan Wilayah dan Investasi Daerah Provinsi Papua Barat (2007-2026). Manokwari.

Hayata \& Febrina, S. (2019). Pengaruh jarak tanam terhadap produktivitas kakao (Theobroma cacao L.) di Desa Betung Kecamatan Kumpeh. Jurnal Media Pertanian, 4, 59-63.

ICCO (2017). Annual Report 2014/2015 International Cocoa Organization. Côte d'Ivoire. Abidjan. Diakses dari https:/ /www.icco.org/about-us/icco-annualreport.html pada tanggal 20 Juli 2020 pukul 10.44 WIT.

IJJDF (1972). Annual Report and Financial Statements. Irian Jaya Joint Development Foundation, Jayapura. Indonesia.

Kadow, B.; J. Bohlman; W. Philips \& R. Lieberel (2013). Identification of main flavour 
compounds in two genotypes of the cocoa tree (Theobroma cacao, L.). Journal Appl. Botany \& Food Quality, $86,90-98$.

Krahmer, A.; A. Engel; D. Kadow; N. Ali; P. Umaharan,; L.W. Kroh \& H. Schultz (2015). Fast and neat - Determination of biochemical quality parameters in cocoa using near infrared spectroscopy. Food Chemical, 181, 152-159.

Lumbantobing, E.M.; S. Rosniawaty \& M.A. Sholeh (2019). Pengaruh dosis dan cara pemberian pupuk anorganik terhadap pertumbuhan kakao (Theobroma cacao L.) belum menghasilkan klon Sulawesi 1. Jurnal Agrikultura, 30, 46-52.

Marpaung, R. (2013). Pertumbuhan bibit kakao (Theobroma cacao. L) dengan pemberian beberapa dosis pupuk NPK (16:16:16) pada tanah ultisol di polybag. Jurnal Ilmiah Universitas Batanghari Jambi, 13, 95-98

Matitaputty, A.; H.R.D. Amanupunyo \& W. Rumahlewang (2014). Kerusakan tanaman kakao (Theobroma cacao L.) akibat penyakit penting di Kecamatan Taniwel Kabupaten Seram Bagian Barat. Jurnal Budidaya Pertanian, 10, 6-9.

Rouw, A. (2019). Evaluasi dan Penyusunan Rencana Tindak Lanjut Pengembangan Kakao di Kabupaten Manokwari Selatan. Laporan Hasil Kajian. Balai Pengkajian Teknologi Pertanian Papua Barat. Manokwari

Rubiyo (2013). Inovasi teknologi perbaikan bahan tanam kakao di Indonesia. Buletin Riset Tanaman Rempah dan Aneka Tanaman Industri, 4, 199-214.
Rubiyo \& Siswanto (2012). Peningkatan produksi dan pengembangan kakao (Theobroma cacao L.) di Indonesia. Buletin Riset Tanaman Rempah dan Aneka Tanaman Industri, 3, 33-48.

Saragih, D.P. \& Ardian (2017). Pengaruh pemberian kompos kulit buah kakao terhadap pertumbuhan bibit kakao hibrida (Theobroma cacao L.). Jurnal Online Mahasiswa Fakultas Pertanian Universitas Riau, 4, 1-12.

Sari, A.P. (2014). Penetapan Komoditas Unggulan Dalam Upaya Pengembangan Agribisnis di Provinsi Papua Barat. Tesis. Institut Pertanian Bogor, Bogor

Utami, R.R.; D. Purnomo \& M.B. Yunindanova (2018). Pengaruh dosis pemupukan terhadap kualitas biji kakao di Punung Pacitan. Agrotechnology Research Journal, 2, 41-46.

Yasa, I.N.A. \& Hadayani (2017). Analisis produksi dan pendapatan usahatani padi sawah di Desa Bonemarawa Kecamatan Riopakava Kabupaten Donggala. E-Jurnal Agrotekbis, 5, 111-118.

Yulianti, N.D.; Ansofino \& Jolianis (2015). Analisis faktor-faktor yang mempengaruhi pendapatan masyarakat transmigrasi di Trans Sakato Jaya Kecamatan Sungai Aur Kabupaten Pasaman Barat. Jurnal Pendidikan Ekonomi STKIP PGRI Sumatera Barat, 1, 1-9.

$$
* * 0 * *
$$

